\title{
Research Aвтіске: A critical study on factors influencing for migration of small and marginal farm family members in Raichur district of Karnataka
}

\author{
a. SHRUTHI, S.K. METI, D.M. CHANDRAGI, S.B. GOUdAPPA AND \\ AMRUTHA T. JOSHI
}

Article Chronicle: Received :

15.07.2017;

Accepted :

30.07.2017

KEY WoRds:

Migration, Factors,

Small farmers,

Marginal farmers
SUMMARY : A study was conducted on purpose and factors influencing the small and marginal farm family members for migration in Raichur district of Karnataka. A purposive and random sampling technique was used to select the samples of taluks (3), villages (6) and migrant small and marginal farmers (60 each) which constituted 120 sample size. The study revealed that large majority (98.30\%) of the small farmers migrated due to push factors like unemployment followed by poor economic condition of the family and low wage rate with 96.60 per cent each. Whereas, large majority $(98.30 \%)$ of the marginal farmers migration was influenced by factors like poor economic condition of the family and agriculture offseason. The purpose or pull factor which influenced for migration of small and marginal farmers were employment $(98.30 \%)$, regular income $(98.30 \%)$ and better amenities (96.60\%), wage differentials $(96.60 \%)$.Hence, the government should ensure for development of non-farm rural activity with the intervention of public private partnership.

How to cite this article : Shruthi, R., Meti, S.K., Chandragi, D.M., Goudappa, S.B. and Joshi, Amrutha T. (2017). A critical study on factors influencing for migration of small and marginal farm family members in Raichur district of Karnataka. Agric. Update, 12(TECHSEAR-5) : 1323-1327; DOI: 10.15740/HAS/AU/ 12.TECHSEAR(5)2017/1323-1327.

Author for correspondence :

\section{R. SHRUTHI}

Department of

Agricultural Extension

Education, College of

Agriculture, University

of Agricultural Sciences,

RAICHUR (KARNATAKA)

INDIA

Email :

shruthishekar9113@

gmail.com

See end of the article for

authors' affiliations 